\title{
The farrier's work environment
}

\author{
Lotta Löfqvist ${ }^{\mathrm{a}, *}$ and Stefan Pinzke ${ }^{\mathrm{a}}$ \\ ${ }^{a}$ Department of Work Science, Business Economics \& Environmental Psychology, Swedish University of \\ Agricultural Sciences. P.O. Box 88, SE-23053 Alnarp, Sweden
}

\begin{abstract}
The horse industry in Sweden has rapidly expanded in recent years. This increasing number of horses implies a greater need for more farriers. Shoeing a horse is hard physical work, and includes awkward work postures and repetitive movements. It is well known that hard physical work increases the risk of injuries and musculoskeletal problems. The risk is especially high for musculoskeletal disorders when certain movements are constantly repeated. Heavy or repeated unilateral loads lead to considerable stress on the muscles, which can lead to rupture and fatigue that can cause long term problems. A case study showed that farriers worked $75 \%$ of their work time with their backs in bent positions (often more than 70 degrees). Farriers are also exposed to risk factors in their physical environment like dust, noise and poor lighting. Risk of kicks and bites, eye injuries and burns are other factors that make their work environment hazardous. There are only a few studies available that have documented the farriers' working environment and these are not of recent date. A US study from 1984 described kicks and bites from horses, metal splinters in the eyes, heat exhaustion and problematic postures to be perceived as the greatest risks in their work. The back, knees and wrists were the most exposed body regions. There is a need for more current and in-depth studies investigating the farriers' working conditions in order to gain more knowledge of their health and work environment. The aim of the present study is to investigate the physical health and work environment of farriers. The investigation will use questionnaires, work load measurements and workplace analysis. The results will serve as a base for improvements concerning the design of the workplace, equipment, tools and aids as well as supplying recommendations about physical exercise and the correct work technique, etc. The results are planned to be incorporated in the education of farriers.
\end{abstract}

Keywords: Musculoskeletal Problems, Questionnaire, Work Environment, Ergonomics

\section{Introduction}

The number of horses in Sweden has increased over the past years. Today, there are more than 360000 horses [12] and more than half a million people are engaged in horseback riding [2]. The huge growth of the horse sector in Sweden has led to an increasing need for professionals in the horse industry among which farriers are in great demand [11].

The work of the farriers has been the same since the profession began; it is still hard and physically demanding. No revolutionary inventions with modern technology have been able to change it. There is strong evidence of an association between MSD and certain work-related physical factors when there are high levels of exposure to such factors, and especially in combination with exposure to more than one physical factor, for example, repetitive lifting of heavy objects in extreme or awkward postures [1]. It is believed that manual material handling, frequent bending and twisting, heavy physical loads, static work postures, repetitive movements, whole-body vibration, or lack of possibility for recovery, can trigger or cause a pathological response that can manifest as MSD [1,4,6,8,10,13]. Farriers are exposed to several of these factors. They often work with hand tools, and with one-sided and repetitive movements especially of the upper extremities. In addition, they are often forced to work in ergonomically unsound positions, for example, with their backs bent in a flexed static position, which can lead to musculoskeletal disorders. A case study showed that the investigated farriers worked $75 \%$ of their time with their backs in a flexed position (often more

\footnotetext{
*Corresponding author. E-mail: lotta.lofqvist@slu.se
} 
than 70 degrees) [5]. In addition to the problems with strenuous working postures, there are the risks of accidents, eye injuries, hearing damage, and factors in the physical environment such as draught, dust and poor lighting conditions [7,9]. There are only a few studies available that have documented the farriers' working situation and these are not recent. A US study from 1984 described the farriers' perceived risks in their work environment [7]. The greatest perceived risks were horse-related (kicks and bites from the horse), metal splinters in the eyes, heat exhaustion and problematic postures. In a master thesis in physiotherapy at Lund University, the farriers' working conditions and physical complaints were examined; the farriers experienced trouble from the lower back $(62 \%)$, knees $(45 \%)$ and wrists $(41 \%)$ [3]. The dynamic expansion of the horse industry during recent years has probably also affected the farriers' work situation. There is, therefore, a need for new studies investigating the farriers' work situation in order to obtain knowledge about perceived symptoms and learn how injuries can be prevented. The overall objective of the study is the prevention of workrelated problems among farriers. Specific objectives are, therefore, that by means of a questionnaire survey and field studies examine farriers' physical health and safety.

\section{Materials and Methods}

\subsection{Subjects}

All members of the Swedish Farrier Association will be offered participation in a questionnaire study.

\subsection{Methods}

A questionnaire will be constructed consisting of questions about work / working conditions (accidents and injury risks, workplace design, furnishings, equipment, tools, stressful tasks, etc.) and workrelated disorders. Furthermore a deeper analysis of the work situation will be performed at approximately ten farriers' work places. Factors such as risk of accidents and injuries in the workplace will be listed and assessed. In addition, work postures, work techniques and work in specific situations will be recorded and analyzed. Which tools, equipment and facilities are designed for different body constitution's anthropometry (hand size, height, arm and leg length) will also be assessed. Interviews, checklists, rating scales, and video recordings will primarily be used in the field studies.

\section{Results}

The results of the study will serve as a basis for the formulation of proposals for health improvement measures in terms of workplace design, the form and development of interior design, equipment, utensils and tools, as well as for the preparation of advice and recommendations to the farriers concerning physical exercise and correct working technique. The results of the survey will also be incorporated in farrier training.

\section{References}

[1] B.P, Bernard. Ed. Musculoskeletal disorders and workplace factors: A critical review of epidemiological evidence for work-related musculoskeletal disorders of the neck, upper extremity, and low back. DHHS (NIOSH) Publication No. 97141. Cincinnati, Ohio: National Institute for Occupational Safety and Health., 1997.

[2] E. Bexelius, D. Johansson, Hästen i Sverige-betyder mer än du tror [The horse in Sweden-means more than you think]. Nationella stiftelsen för hästhållningens främjande, 2004. In Swedish.

[3] H. Bojko, L. Boman and K. Eneström, Hovslagare belastningsbesvär, arbetsmetoder, information, träningsprogram [farriers musculoskeletal disorders, work practices, information and training]. Bachelor thesis. Lund University, 1985. In swedish.

[4] P.M. Bongers, C.R. de Winter, M.A. Kompier, and V.H. Hildebrandt, Psychosocial factors at work and musculoskeletal disease. Scandinavian J. Work Environ. Health 19 (1993), 297-312.

[5] C. Fiorentini, S. Mattioli, F. Graziosi, R. Bonfiglioli, T.J. Armstrong and F.S. Violante, Occupational relevance of subclavian vein thrombosis in association with thoracic outlet syndrome, Scand J Work Environ Health, 31(2005), 160-163.

[6] M. Hagberg, B. Silverstein, R. Wells, M.J. Smith, H.W. Hendrick, P. Carayon, and M. Pérusse, Work-Related MusculoSkeletal Disorders (WMSDs): A Reference Book for Prevention. London, U.K.: Taylor and Francis, 1995.

[7] A. Holler, Occupational hazards of farriers, Am Ind Assoc J, 45 (1984), 34-38

[8] NRC. Musculoskeletal disorders and the workplace: Low back and upper extremities. Washington DC, National Research council, Panel on Musculoskeletal disorders and the Workplace. 2001

[9] Prevent. Work and technology on human terms. G. Hägg, M. Ericsson and P. Odenrick, Physical load (2008), pp.129-189.

[10] L. Punnett and D.H. Wegman, Work-related musculoskeletal disorders: the epidemiologic evidence and the debat. J Electromyogr Kinesiol 14 (2004), 13-23.

[11] Swedish Public Employment Service, www.af.se, 2011 
[12] The Swedish board of agriculture. Hästar och anläggningar med häst 2010 [Horses and facilities with horses] JO 24 SM 1101, 2011. In swedish, summary in english.
[13] A.J. van der Beek and M.H. Friings-Dresen, Assesment of mechanical exposure in ergonomic epidemiology, Occup Environ Med, 55 (1998), 291-299. 